JMI Vol. 43 No. 2, Desember 2021

METAL INDONESIA

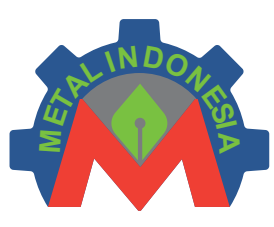

Journal Homepage:

http://www.jurnalmetal.or.id/index.php/jmi

p-issn: 0126-3463

e-issn: 2548-673X

\title{
PENGARUH VARIASI TEMPERATUR SINTERING PADA PROSES METAL INJECTION MOLDING TERHADAP DENSITAS, POROSITAS, DAN KEKERASAN SINTER PART BERBAHAN SS 17-4 PH
}

\section{EFFECT OF SINTERING TEMPERATURE OF METAL INJECTION MOLDING PROCESS ON DENSITY, POROSITY, AND HARDNESS OF SS 17-4 PH POWDER}

\author{
Apang Djafar Shieddieque ${ }^{1}$, Amri Abdulah ${ }^{1 *}$, Moch Iqbal Zaelana Muttahar ${ }^{2}$, Raja Mualtio \\ Panggabean $^{1}$ \\ ${ }^{1}$ Jurusan Teknik Mesin Sekolah Tinggi Teknologi Wastukancana, Purwakarta \\ Jalan Cikopak No 53 Purwakarta 41151, Jawa Barat Indonesia \\ ${ }^{2}$ Balai Besar Logam dan Mesin-Kementerian Perindustrian \\ Jl. Sangkuriang No. 12 - Bandung 40135, Jawa Barat, Indonesia \\ E-mail : amri@stt-wastukancana.ac.id
}

\begin{abstract}
Abstrak
Metal Injection Molding (MIM) yaitu gabungan dari proses powder metallurgy dan plastic injection molding yang diterapkan pada pembuatan produk/komponen yang memerlukan sifat mekanis yang tinggi (high performance), fleksibilitas desain dan material, permukaan yang baik, dan jumlah produksi yang tinggi sehingga dapat meminimalisir biaya manufaktur. Proses ini dapat diterapkan pada berbagai jenis material termasuk material logam maupun keramik seperti superalloy, baja tahan karat, titanium, karbida, zirconia dan lain-lain. Dalam penelitian ini metal injection molding untuk aplikasi ortodontik dilakukan dengan basis bahan stainless steel 17-4 $\mathrm{PH}$ selain itu ditambahkan variasi temperatur sebesar $1200^{\circ} \mathrm{C}, 1250^{\circ} \mathrm{C}$, dan $1300^{\circ} \mathrm{C}$ selama 2 jam, untuk melihat perbandingan nilai densitas, struktur mikro, dan kekerasan sampel dari proses perbandingan nilai densitas didapatkan hasil nilai rata-rata variasi temperatur $1200^{\circ} \mathrm{C}$ sebelum sintering $67,31 \%$, setelah sintering $86,07 \%$, variasi temperatur $1250^{\circ} \mathrm{C}$ sebelum sintering $68,62 \%$, setelah sintering $89,50 \%$, variasi temperatur $1300^{\circ} \mathrm{C}$ sebelum sintering $69,31 \%$, setelah sintering $91,48 \%$, dari proses pengujian metalografi didapatkan hasil porositas sebesar $12 \%$ pada temperatur $1200^{\circ} \mathrm{C}$, variasi temperatur $1250^{\circ} \mathrm{C}$ didapatkan hasil porositas sebesar $5 \%$, variasi temperatur $1300^{\circ} \mathrm{C}$ didaparkan hasil porositas sebesar $9 \%$, dari proses pengujian kekerasan didapatkan hasil rata-rata variasi temperatur $1200^{\circ} \mathrm{C} 59,3 \mathrm{HV}$, variasi temperatur $1250^{\circ} \mathrm{C} 88,9$ $\mathrm{HV}$, variasi temperatur $1300^{\circ} \mathrm{C} 70,275 \mathrm{HV}$.
\end{abstract}

Kata Kunci: Metal injection molding, stainless steel 17-4 PH, sintering, kekerasan, densitas.

\footnotetext{
Abstract

Metal Injection Molding (MIM) is a combination of powder metallurgy and plastic injection molding processes that are applied to the manufacture of products/components that require high mechanical properties (high performance), design and material flexibility, good surface, and high production quantities so that they can minimize manufacturing costs. This process can be applied to various types of materials including metallic and ceramic materials such as superalloys, stainless steels,
} 
titanium, carbides, zirconia and others. In this study, metal injection molding for orthodontic applications has been made with 17-4 PH stainless steel base, in addition to adding temperature variations of $1200^{\circ} \mathrm{C}$, $1250^{\circ} \mathrm{C}$, and $1300^{\circ} \mathrm{C}$ for 2 hours, to compare the density values, microstructure, and the hardness of the sample from the density value comparison process, the average temperature variation is $1200^{\circ} \mathrm{C}$ before sintering $67.31 \%$, after sintering $86.07 \%$, temperature variation $1250^{\circ} \mathrm{C}$ before sintering $68.62 \%$, after sintering $89,50 \%$, temperature variation $1300^{\circ} \mathrm{C}$ before sintering $69.31 \%$, after sintering $91.48 \%$, from the metallographic testing process obtained $12 \%$ porosity at a temperature of $1200^{\circ} \mathrm{C}$, temperature variation $1250^{\circ} \mathrm{C}$ obtained porosity of $5 \%$, temperature variation $1300^{\circ} \mathrm{C}$ obtained $9 \%$ porosity, from the hardness testing process the average temperature variation was $1200^{\circ} \mathrm{C} 59.3 \mathrm{HV}$, temperature variation $1250^{\circ} \mathrm{C} 88.9 \mathrm{HV}$, temperature variation $1300^{\circ} \mathrm{C} 70,275 \mathrm{HV}$.

Keywords : Metal injection molding, stainless steel 17-4 PH, sintering, hardness, density.

\section{PENDAHULUAN}

Metal injection molding telah di produksi sejak tahun 1970-an. Selama waktu itu pasar telah berkembang pesat dengan menyertakan beragam aplikasi keberhasilan awal adalah pada bracket, ortodonti gigi, case jam tangan, dan senjata api, sebagai contoh perawarat ortodonti memiliki tujuan masing-masing diantaranya mastikasi untuk merapihkan gigi dan estetika atau memperindah tampilan wajah seseorang. Pembuatan braket harus dilakukan dengan proses yang sesuai untuk menghasilkan hasil yang bagus. Proses yang biasa digunakan adalah investment casting, machining, dan metal injection molding. Investment Casting memiliki kelemahan yaitu kekasaran permukaan yang cukup tinggi untuk standart dan memerlukan proses lebih lanjut. Pemesinan dilakukan dengan menghilangkan bagian yang tidak diinginkan untuk mendapatkan keinginan bentuk, sedangkan bentuk braket membutuhkan ketelitian yang tinggi dan cukup rumit maka dari itu di buat menggunakan proses Metal injection molding

Dari penelitian yang sudah dilakukan didapatkan bahwa Hasilnya menunjukkan bahwa kerapatan pada proses sintering menggunakan argon relatif tinggi $87 \%$, susut homogen relatif dan kekerasan tinggi dicapai dengan sintering pada $1360^{\circ} \mathrm{C}$ untuk 1,5 jam dan atmosfer argon. Namun, produk MIM memiliki rentang kerapatan relatif dari 98-99\%. Hasil densitas relatif rendah mungkin disebabkan oleh tekanan injeksi rendah selama proses cetakan pemadatan (Shieddieque et al., 2021).

Parameter sintering meliputi temperatur (T), waktu tahan/holding, atmosfer sintering dan jenis material. Kombinasi parameter tersebut menyebabkan mekanisme sintering cukup kompleks. Ketika temperatur naik, akan terjadi proses difusi antar partikel-partikel logam, sehingga membuat kekuatan, kepadatan, keuletan, thermal, dan konduktivitas elektris meningkat. Tahap yang kedua dari sintering adalah fase transpor uap (vapor-phase transport). Pada saat dipanaskan hingga akan mencapai titik leburnya, partikel-partikel akan berubah menjadi uap, setelah itu temperatur didinginkan dan uap akan memadat kembali. Jika dua partikel dari jenis logam yang berbeda dipanaskan bersamasama, maka partikel yang memiliki titik lebur lebih rendah akan mencair terlebih dahulu dan mengikat partikel yang tidak melebur. Peristiwa ini disebut liquid-phase transport.

Penelitian ini berfokus pada proses sintering dengan memvariasikan temperatur sebesar $1200^{\circ} \mathrm{C}-1250^{\circ} \mathrm{C}$ dan $1300^{\circ} \mathrm{C}$ (selama kurun waktu 2 jam) proses dilakukan terhadap perubahan densitas produk, kekerasan, dan mikrostruktur pada tablet berbahan SS 17-4 PH.

\section{METODOLOGI}

\section{Bahan dan Proses Penelitian}

Dalam proses sintering berbahan material stainless steel 17-4 PH, metode penelitian yang dilakukan ditunjukkan pada Gambar 1.

Serbuk SS 17-4 PH ditimbang dengan berat sekitar 2,5 hingga 2,8 gram kemudian dikompaksi dengan tekanan sebesar 100 bar untuk menghasilkan tinggi spesimen sekitar 3,13,4 $\mathrm{mm}$ dengan diameter silinder sebesar $10 \mathrm{~mm}$. Ukuran tersebut ditentukan untuk mencapai densitas terukur sebesar $70 \%$.

Sintering dilakukan setelah pengepresan dan pengukuran massa dan dimensi sampel. Proses sintering diawali dengan flushing tungku 
yang dilakukan sebanyak 3 kali dalam rentan waktu 15 menit, setelah flushing sampel dimasukkan kedalam tungku disertai pengaturan pada tungku dengan variasi temperatur $1200^{\circ} \mathrm{C}$, $1250^{\circ} \mathrm{C}$ dan $1300^{\circ} \mathrm{C}$ selama $2 \mathrm{jam}$.

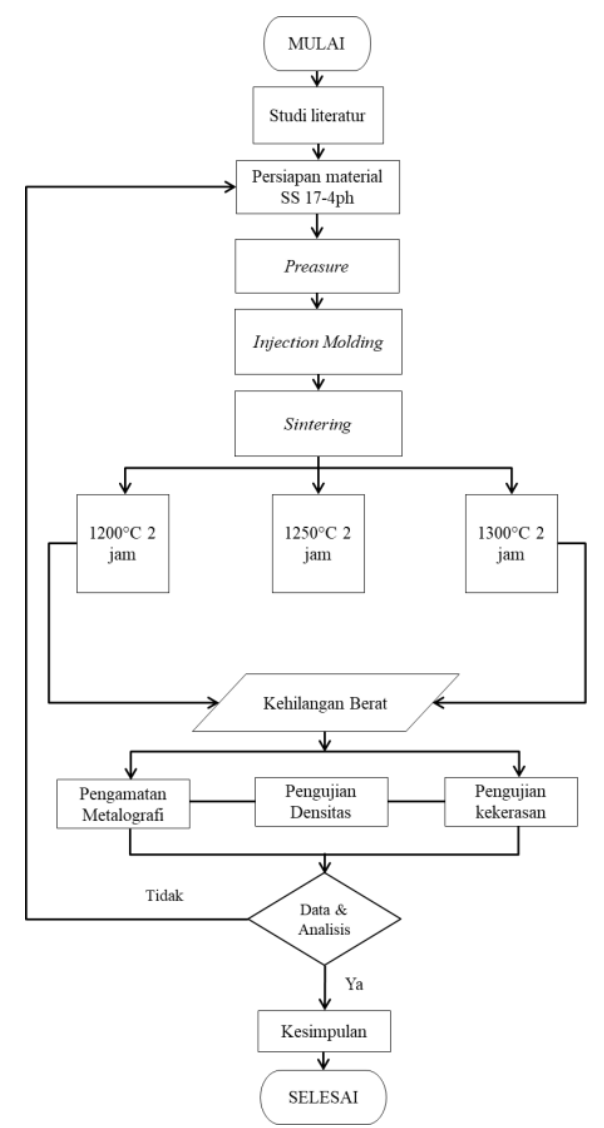

Gambar 1. Alur penelitian sintering SS 17-4 PH

\section{Pengujian}

Pengamatan metalografi dilakukan melalui proses mounting terhadap sampel hasil sintering yang kemudian di-grinding dan dipolishing dengan menggunakan kain beludru dan alumina. Etsa dilakukan dnegan menggunakan aqua regia. Pada saat permukaan sampel sudah halus dan bening maka dilanjutkan pada pengamatan metalografi untuk melihat tingkat porositas pada sampel.

Pengujian densitas dilakukan dengan cara penimbangan dan pengukuran sampel pada saat sebelum dan setelah sintering, ketika pengambilan data sudah dilakukan dilanjutkan dengan perhitungan data untuk mencari nilai densitas rat-rata (bulk density). Setelah densitas didaptkan, selanjutnya dilakukan pengujian kekerasan dengan metode Vickers, dilakukan beberapa kali indentasi pada titik yang berbeda agar didapatkan nilai yang representatif terhadap sampel.

\section{HASIL DAN PEMBAHASAN Pengujian Densitas}

Pada hasil pengujian ini, Stainless Steel 17-4 PH yang sudah melalu proses sintering dengan tiga variasi suhu yang berbeda antara, $1200^{\circ} \mathrm{C}, 1250^{\circ} \mathrm{C}$ dan $1300^{\circ} \mathrm{C}$ dan di ketahui densitas Stainless steel adalah $7,75 \mathrm{~g} / \mathrm{cm}^{3}$ (azom.com, 2021). Pada Tabel 1 memperlihatkan komposisi standar pada stainless steel 17-4 PH data ini didapatkan dari (Desktop Metal, 2018).

Tabel 1. komposisi standar stainless steel 17-4 $\mathrm{PH}$

\begin{tabular}{|l|r|}
\hline $\mathrm{C}$ & $0.07(\mathrm{max})$ \\
\hline $\mathrm{Cr}$ & $15.5-17.5$ \\
\hline $\mathrm{Ni}$ & $3-5$ \\
\hline $\mathrm{Cu}$ & $3-5$ \\
\hline $\mathrm{Mn}$ & $1.0(\max )$ \\
\hline $\mathrm{nb}+\mathrm{Ta}$ & $\mathbf{0 . 1 5}-0.45$ \\
\hline
\end{tabular}

Matriks penelitian ditunjukkan pada Tabel 2. Sedangkan data pengukuran sampel sebelum dilakukan sintering ditunjukkan pada Teabel 3.

Tabel 2. Kode sampel dan variasi temperatur

\begin{tabular}{|c|c|c|c|c|c|}
\hline \multirow{2}{*}{$\begin{array}{l}\text { Waktu } \\
\text { jam }\end{array}$} & \multirow{2}{*}{$\begin{array}{c}\begin{array}{c}\text { Tempe } \\
\text { ratur }\end{array} \\
{ }^{\circ} \mathrm{C}\end{array}$} & \multicolumn{2}{|c|}{$\begin{array}{l}\text { Densitas } \\
\text { Terhitung }\end{array}$} & \multirow{2}{*}{$\begin{array}{c}\text { Sample } \\
\text { No }\end{array}$} & \multirow{2}{*}{$\begin{array}{l}\text { Kode } \\
\text { Sample }\end{array}$} \\
\hline & & $\begin{array}{c}\mathrm{g} / \\
\mathrm{cm}^{3}\end{array}$ & $\%$ & & \\
\hline \multirow{8}{*}{2} & \multirow{3}{*}{1200} & 7,75 & 70 & A & $27 \mathrm{~A}$ \\
\hline & & 7,75 & 70 & B & 27B \\
\hline & & 7,75 & 70 & C & $27 \mathrm{C}$ \\
\hline & \multirow{3}{*}{1250} & 7,75 & 70 & A & $37 \mathrm{~A}$ \\
\hline & & 7,75 & 70 & B & 37B \\
\hline & & 7,75 & 70 & C & $37 \mathrm{C}$ \\
\hline & \multirow{2}{*}{1300} & 7,75 & 70 & A & $47 \mathrm{~A}$ \\
\hline & & 7,75 & 70 & B & 47B \\
\hline
\end{tabular}




\begin{tabular}{|l|l|l|l|l|l|}
\hline & & 7,75 & 70 & $\mathrm{C}$ & $47 \mathrm{C}$ \\
\hline
\end{tabular}

Tabel 3. Data sampel sebelum di sintering

\begin{tabular}{|c|c|c|c|c|c|c|c|}
\hline \multicolumn{8}{|c|}{ Sebelum sintering } \\
\hline \multirow{2}{*}{$\begin{array}{l}\mathrm{N} \\
\mathrm{O}\end{array}$} & \multirow{2}{*}{$\begin{array}{c}\text { Tem } \\
\text { perat } \\
\text { ur } \\
{ }^{\circ} \mathrm{C}\end{array}$} & \multirow{2}{*}{$\begin{array}{l}\text { W } \\
\text { ak } \\
\text { tu } \\
\text { ja } \\
\text { m }\end{array}$} & \multirow{2}{*}{$\begin{array}{c}\text { Ber } \\
\text { at } \\
g\end{array}$} & \multirow{2}{*}{$\begin{array}{c}\begin{array}{c}\text { Teb } \\
\text { al }\end{array} \\
\mathrm{mm}\end{array}$} & \multirow{2}{*}{$\begin{array}{c}\begin{array}{c}\text { Dia } \\
\text { met } \\
\text { er }\end{array} \\
\mathrm{Cm}\end{array}$} & \multicolumn{2}{|c|}{$\begin{array}{c}\text { Perhitungar } \\
\text { Densitas }\end{array}$} \\
\hline & & & & & & $\begin{array}{c}\mathrm{g} / \\
\mathrm{cm}^{3}\end{array}$ & $\%$ \\
\hline 1 & \multirow{3}{*}{1200} & 2 & 1,5 & $\begin{array}{c}3,6 \\
5\end{array}$ & 1 & 5,24 & $\begin{array}{l}67, \\
55\end{array}$ \\
\hline 2 & & 2 & 1,5 & $\begin{array}{c}3,6 \\
6\end{array}$ & 1 & 5,22 & $\begin{array}{l}67, \\
37\end{array}$ \\
\hline 3 & & 2 & 1,5 & $\begin{array}{c}3,6 \\
8\end{array}$ & 1 & 5,19 & $\begin{array}{l}67, \\
00\end{array}$ \\
\hline 4 & \multirow{3}{*}{1250} & 2 & 1,5 & $\begin{array}{c}3,5 \\
5\end{array}$ & 1 & 5,38 & $\begin{array}{l}69, \\
45\end{array}$ \\
\hline 5 & & 2 & 1,5 & $\begin{array}{c}3,5 \\
8\end{array}$ & 1 & 5,34 & $\begin{array}{l}68, \\
87\end{array}$ \\
\hline 6 & & 2 & 1,5 & $\begin{array}{c}3,6 \\
5\end{array}$ & 1 & 5,24 & $\begin{array}{l}67, \\
55\end{array}$ \\
\hline 7 & \multirow{3}{*}{1300} & 2 & 1,5 & $\begin{array}{c}3,6 \\
2\end{array}$ & 1 & 5,28 & $\begin{array}{r}68, \\
11\end{array}$ \\
\hline 8 & & 2 & 1,5 & $\begin{array}{c}3,6 \\
3\end{array}$ & 1 & 5,26 & $\begin{array}{l}67, \\
92\end{array}$ \\
\hline 9 & & 2 & 1,5 & $\begin{array}{c}3,4 \\
3\end{array}$ & 1 & 5,57 & $\begin{array}{l}71, \\
88\end{array}$ \\
\hline
\end{tabular}

Gambar 2-4 menunjukkan diagram perbandingan densitas sebelum dan setelah dilakukan proses sintering.

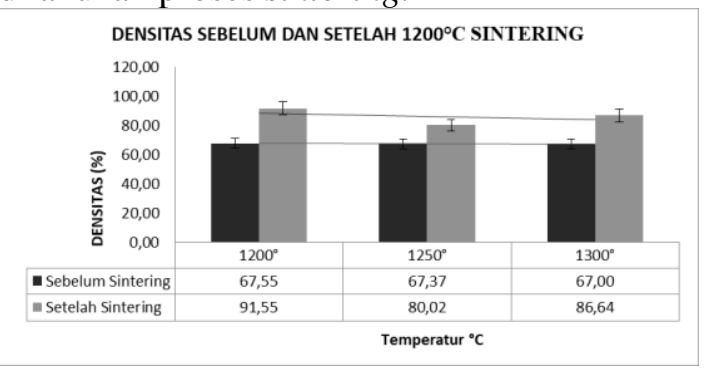

Gambar 2. Grafik perbandingan densitas pada temperatur sebesar $1200{ }^{\circ} \mathrm{C}$

Pada temperatur $1200{ }^{\circ} \mathrm{C}$ nilai densitas sebelum dilakukannya sintering yaitu ada pada kisaran sebesar 60-67,55\%. Setelah dilakukan proses sintering sampel mengalami peningkatan densitas hingga 91,55\% dari densitas SS 17-4 $\mathrm{PH}$.

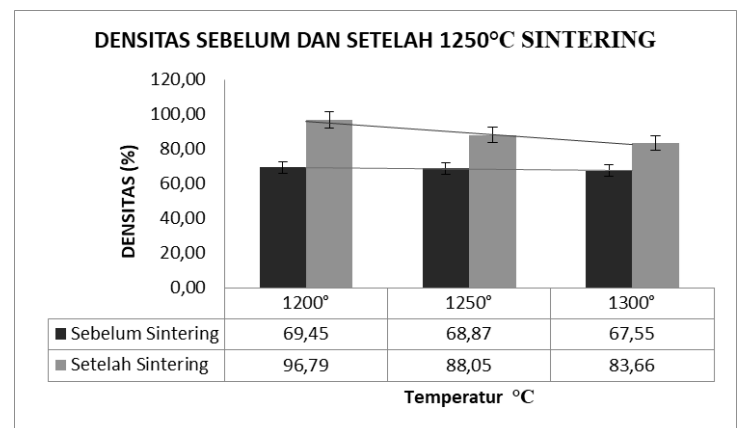

Gambar 3. Grafik perbandingan densitas pada temperatur sebesar $1250{ }^{\circ} \mathrm{C}$

Pada temperatur $1250{ }^{\circ} \mathrm{C}$ nilai densitas sebelum dilakukannya sintering yaitu ada pada kisaran sebesar 67,55-69,45\%. Setelah dilakukan proses sintering sampel mengalami peningkatan densitas hingga 96,79\% dari densitas SS 17-4 PH

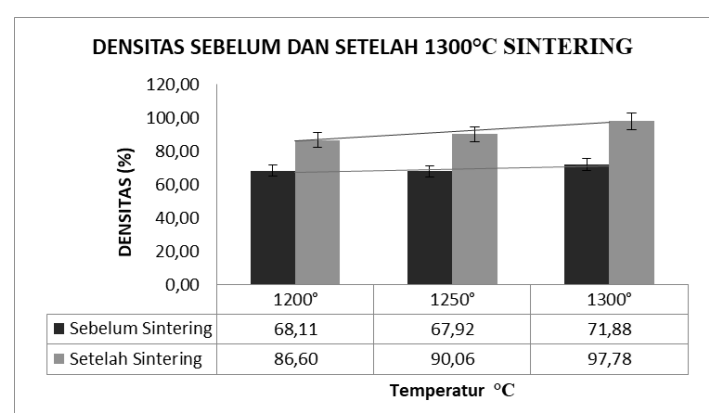

Gambar 4. Grafik perbandingan densitas pada temperatur sebesar $1300{ }^{\circ} \mathrm{C}$

Pada temperatur $1250{ }^{\circ} \mathrm{C}$ nilai densitas sebelum dilakukannya sintering yaitu ada pada kisaran sebesar 67,92-71,88\%. Setelah dilakukan proses sintering sampel mengalami peningkatan densitas hingga 90,06\% dari densitas SS 17-4 PH

Tabel 4 menunjukkan hasil rata-rata densitas dengan variasi temperatur sebesar $1200^{\circ} \mathrm{C}, 1250^{\circ} \mathrm{C}$, dan $1300^{\circ} \mathrm{C}$, grafik mengalami peningkatan pada setiap temperatur setelah dilakukannya proses sintering. Grafik perbandingan densitas setelah sintering ditunjukkan pada Gambar 5. 
Tabel 5. densitas rata-rata sebelum dan sesudah sintering

\begin{tabular}{|c|c|c|c|c|}
\hline \multirow{2}{*}{ No } & \multicolumn{4}{|c|}{ Densitas rata-rata } \\
\cline { 2 - 5 } & $\begin{array}{c}\text { Tempe } \\
\text { ratur }^{\circ} \\
\mathrm{C}\end{array}$ & Waktu & $\begin{array}{c}\text { Sebel } \\
\text { um } \\
\text { sinter } \\
\text { ing }\end{array}$ & $\begin{array}{c}\text { Sesuda } \\
\mathrm{h} \\
\text { sinterin } \\
g\end{array}$ \\
\hline 1 & 1200 & 2 jam & 67,31 & 86,07 \\
\hline 2 & 1250 & 2 jam & 68,62 & 89,50 \\
\hline 3 & 1300 & 2 jam & 69,31 & 91,48 \\
\hline
\end{tabular}

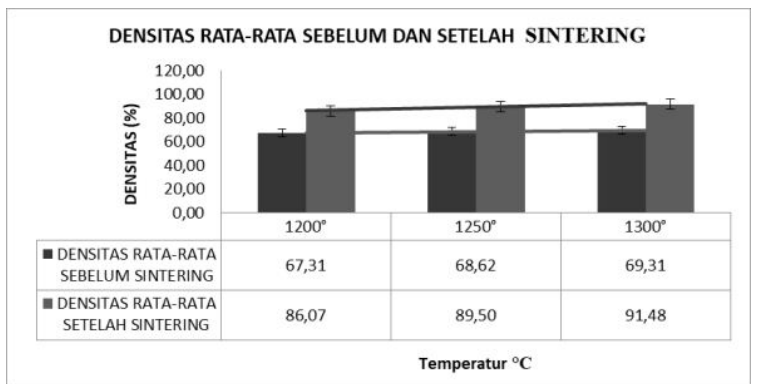

Gambar 5. densitas rata-rata sebelum dan setelah di-sintering

\section{Pengamatan Metalografi}

Pengamatan metalografi menghasilkan tingkat porositas yang dapat dilihat pada microscope optic, Pengamatan sebelum dilakukan pengetsaan di tunjukan pada Gambar 6-8. Analisis berikutnya dengan cara mempolish dan diberi etsa, pengetsaan dilakukan menggunakan Aqua Regia $=(\mathrm{HN} 03+\mathrm{HCI})$ kemudian dilihat struktur mikro dengan pembesaran 500x.

Pada Gambar 6 menunjukan gambar sampel A1 dengan variasi temperatur sebesar $1200^{\circ} \mathrm{C}$ sebelum dilakukan struktru mikro, Gambar 7 menunjukan sampel A2 dengan variasi temperatur sebesar $1250^{\circ} \mathrm{C}$, dan Gambar 8 menunjukan gambar sampel A3 dengan variasi temperatur sebesar $1300^{\circ} \mathrm{C}$.

Pada Gambar 9 menunjukan hasil dari pemngamatan metalografi pada sampel A1 dengan temperatur sintering $1200^{\circ} \mathrm{C}$ setelah dilakukan polishing dan etching dengan pembesaran $500 \mathrm{x}$

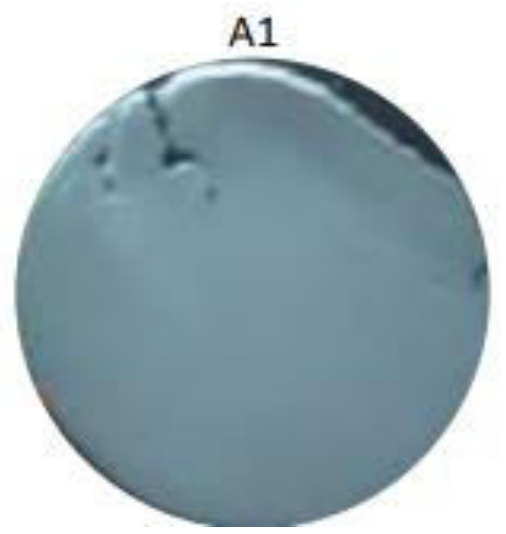

Gambar 6. sampel A1 $1200^{\circ} \mathrm{C}$, permukaan sampel sebelum polish

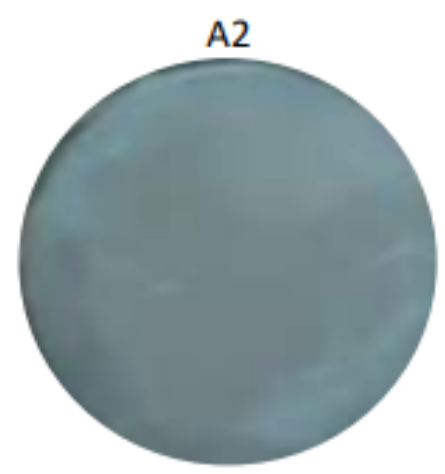

Gambar 7. sampel A2 $1250^{\circ} \mathrm{C}$, permukaan sampel sebelum polish

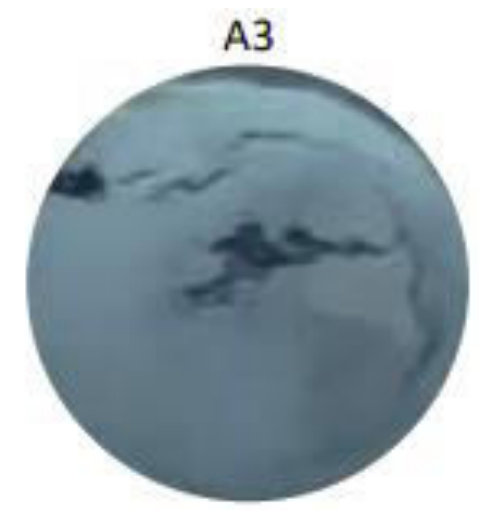

Gambar 8. sampel A3 $1300^{\circ} \mathrm{C}$, permukaan sampel sebelum polish 


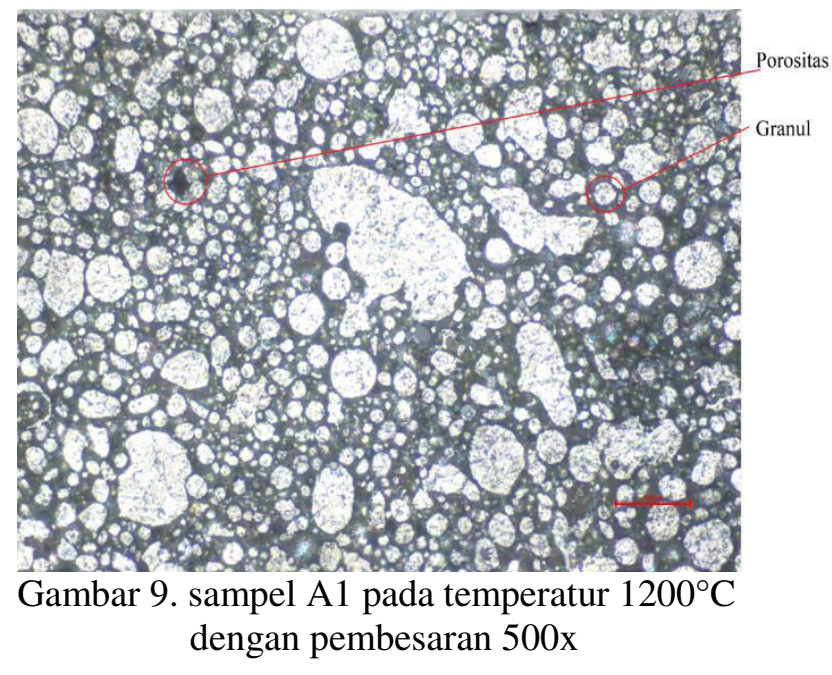

Gambar 9 menunjukkan bentuk butir yang berbentuk dengan kecenderungan membulat, pada sampel A1 dengan variasi temperatur $1200^{\circ} \mathrm{C}$, ketika sudah dilakukan perhitungan menggunakan metode grain counting maka didapatkan hasil sebesar 12\% porositas. Gambar 10 menunjukan hasil dari pengamatan metalografi pada sampel A2 dengan temperatur $1250^{\circ} \mathrm{C}$ sintering setelah dilakukan polishing dan etching dengan pembesaran 500x. porositas terhitung sebesar $5 \%$ pada sampel dengan temperatur sintering sebesar $1250{ }^{\circ} \mathrm{C}$.

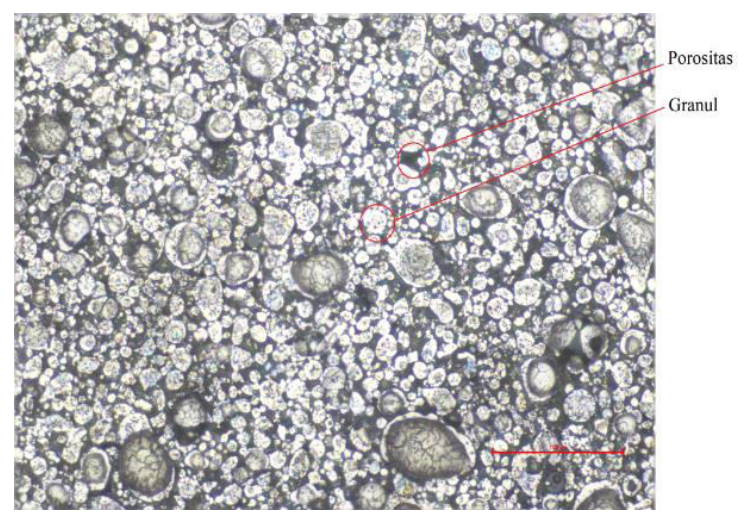

Gambar 10. sampel A2 pada temperatur $1250^{\circ} \mathrm{C}$ dengan pembesaran 500x

Gambar 11 menunjukkan hasil metalografi sampel A3 dengan variasi temperatur $1300^{\circ} \mathrm{C}$. Terlihat bentuk butir yang didapat berbentuk berbagai macam bentuk, pada sampel A3 dengan variasi temperatur $1300^{\circ} \mathrm{C}$, ketika sudah dilakukan perhitungan menggunakan metode grain counting maka didapatkan hasil sebesar $9 \%$ porositas.

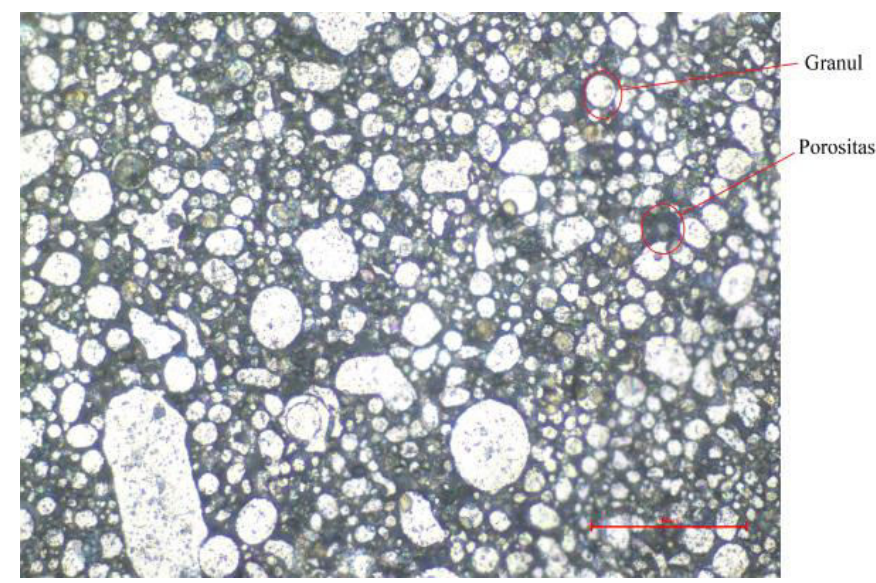

Gambar 11. sampel A3 pada temperatur $1300^{\circ} \mathrm{C}$ demgan pembesaran 500x

Jadi hasil dari semua sampel A1, A2, A3 dengan variasi temperatur $1200^{\circ} \mathrm{C}, 1250^{\circ} \mathrm{C}$, dan $1300^{\circ} \mathrm{C}$ selama 2 jam didapatkan yaitu, pada sampel A1 terlihat pada mikrostruktur lebih banyak butir dibandingkan dengan porositas, berbeda dengan sampel A2 terlihat banyak kerapatan antar batas butir dan butir dan tidak banyak rongga pada sampel tersebut, pada sampel A3 sama seperti sampel A1 lebih banyak batas butir dibandingkan dengan porositas nya, jadi sampel yang paling optimum terdapat pada sampel A2 dikarenakan batas butir dan porositas tidak terlalu besar.

\section{Hasil Pengujian Kekerasan Vickers}

Hasil pengujian kekerasan dengan menggunakan metode vickers dari bahan stainlees steel 17-4 PH yang melalui proses sintering dengan variasi temperatur berbeda antara $1200^{\circ} \mathrm{C}, 1250^{\circ} \mathrm{C}$ dan $1300^{\circ} \mathrm{C}$. Tabel 6 merupakan data hasil dari kekerasan dan rata-rata hasil pengujian kekerasan Vickers pada variasi temperatur $1200^{\circ} \mathrm{C}, \quad 1250^{\circ} \mathrm{C}$ dan $1300^{\circ} \mathrm{C}$ sintering dengan waktu selama 2 jam. Gambar 12 menunjukkan grafik hasil pengujian kekerasan vickers dengan variasi temperatur $1200^{\circ} \mathrm{C}$, $1250^{\circ} \mathrm{C}$ dan $1300^{\circ} \mathrm{C}$ dengan waktu selama 2 jam. 
Tabel 6. tabel data kekerasan dan rata - rata kekerasan (Vickers)

\begin{tabular}{|c|c|c|c|c|}
\hline \multirow{2}{*}{ No } & $\begin{array}{c}\text { Tempera } \\
\text { tur }\end{array}$ & \multicolumn{2}{|c|}{ Kekerasan } & \multirow{2}{*}{$\begin{array}{c}\text { Rata- } \\
\text { rata }\end{array}$} \\
\cline { 2 - 4 } & ${ }^{\circ} \mathrm{C}$ & \multicolumn{2}{|c|}{$\mathbf{H V}$} & HV \\
\hline \multirow{2}{*}{1} & \multirow{2}{*}{1200} & 64,2 & 66,5 & \multirow{2}{*}{59,3} \\
\cline { 3 - 4 } & & 50,2 & 56,3 & \\
\hline \multirow{2}{*}{2} & \multirow{2}{*}{1250} & 68,4 & 69,6 & \multirow{2}{*}{88,9} \\
\cline { 3 - 4 } & & $\begin{array}{c}112, \\
1\end{array}$ & $\begin{array}{c}105, \\
5\end{array}$ & \\
\hline \multirow{2}{*}{3} & \multirow{2}{*}{1300} & 59,7 & 55,5 & \multirow{2}{*}{70,275} \\
\cline { 3 - 4 } & & 81,5 & 84,4 & \\
\hline
\end{tabular}

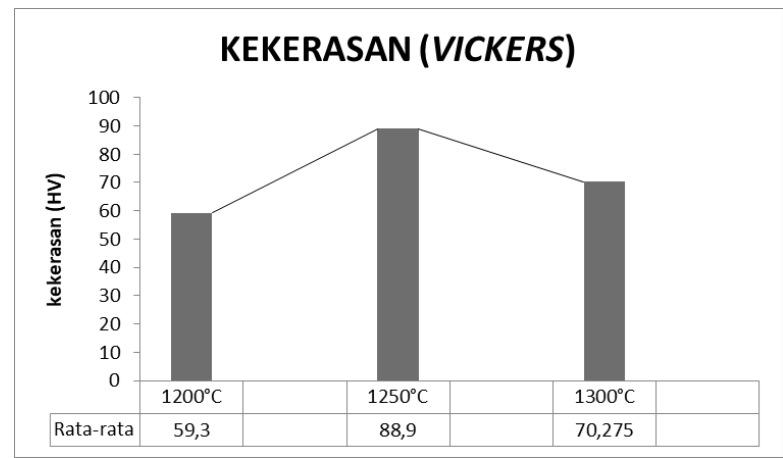

Gambar 12. Kekerasan (Vickers) hasil sintering pada berbagai temperatur

Gambar 4.11 menunjukan grafik hasil pengujian kekerasan vickers dengan variasi temperatur $1200^{\circ} \mathrm{C}, 1250^{\circ} \mathrm{C}$ dan $1300^{\circ} \mathrm{C}$ dengan waktu selama 2 jam, berarti nilai kekerasan material yang diuji coba selama 2 kali dengan variasi temperatur hasilnya mengalami perbadaan yang agak jauh berbeda. Hasil yang didapat berbeda-beda dikarenakan permukaan dari spesimen hasil sintering memiliki permukaan yang rapuh dibeberapa bagian, hal ini bisa disebabkan karena oksidasi pada powder atau kurangnya tekanan yang diberikan saat proses kompaksi sehingga kurangnya ikatan fisik yang terbentuk antar butir 17-4 PH. Pada saat pemasangan spesimen kesalahan terjadi tergantung pada lengkungan, beban, penumbuk, dan kekerasan bahan. Hasil yang paling optimum didapatkan pada proses sintering pada temperatur $1250^{\circ} \mathrm{C}$ sebesar $88,9 \mathrm{HV}$.

\section{KESIMPULAN}

Adapun kesimpulan yang didapatkan dari penelitian seperti berikut :

Hasil dari variasi temperatur sintering terhadap densitas. Sampel pada temperatur $1200^{\circ} \mathrm{C}$ dengan kode sampel 27B setelah disintering, memiliki nilai terendah yaitu 6,20 $\mathrm{g} / \mathrm{cm}^{3}$ dengan presentase densitas sebesar $80,02 \%$, sampel pada temperatur $1300^{\circ} \mathrm{C}$ dengan kode sampel 47C, memiliki nilai densitas tertinggi yaitu $7,58 \mathrm{~g} / \mathrm{cm}^{3}$ dengan presentase densitas 97,78\%. Hal tersebut dikarenakan semakin tinggi temperatur sintering maka sampel akan semakin padat sehingga memiliki nilai densitas yang besar.

Terdapat hasil dari variasi temperatur sintering $1200^{\circ} \mathrm{C}, 1250^{\circ} \mathrm{C}$ dan $1300^{\circ} \mathrm{C}$ selama 2 jam terhadap porositas, setelah dilakukan perhitungan menggunakan metode grain counting pada sampel A1 didapatkan hasil porositas sebesar $12 \%$, pada sampel A2 didapatkan hasil porositas sebesar 5\%, pada sampel A3 didapatkan hasil porositas sebesar 9\%, maka didapatkan sampel yang paling optimum ada pada sampel A2 dengan temperatur $1250^{\circ} \mathrm{C}$, karena batas butir dan total porositas tidak terlalu besar.

Terdapat hasil dari variasi temperatur sintering terhadap nilai kekerasan vickers, sampel pada variasi temperatur $1200^{\circ} \mathrm{C}$ memiliki nilai kekerasan terendah dengan nilai rata-rata keseluruhan titik yaitu 59,3 HV, sedangkan untuk sampel pada temperatur $1250^{\circ} \mathrm{C}$ dengan nilai rata-rata keseluruhan titik yaitu $88,9 \mathrm{HV}$, nilai kekerasan Vickers material yang diuji coba 2 kali, menggunakan 3 kali variasi temperatur $1200^{\circ} \mathrm{C}$, $1250^{\circ} \mathrm{C}$ dan $1300^{\circ} \mathrm{C}$ hasilnya mengalami perbedaan, mengakibatkan kurangnya signifikan, hal tersebut bisa jadi dikarenakan terlalu lamanya meterial didalam tungku

\section{DAFTAR PUSTAKA}

Afrilinda, E., Virdhian, S., \& Doloksaribu, M. (2017). Studi Awal Pembuatan Feedstock Metal Injection Moulding Menggunakan Torque Rheometer. Metal Indonesia, 39(1), 33. https://doi.org/10.32423/jmi.2017.v39.3 3-44. 
azom.com. (2021). Stainless Steel Grade 17$4 \quad$ UNS $\quad$ S17400 ). https://www.azom.com/article.aspx?Arti cleID $=6778$

Barriere, T., Liu, B., \& Gelin, J. C. (2003). Determination of the optimal process parameters in metal injection molding from experiments and numerical modeling. Journal of Materials Processing Technology, 143-144(1), 636-644.

https://doi.org/10.1016/S0924-

0136(03)00473-4

Desktop Metal. (2018). 17-4 PH Stainless Steel. Www.Desktopmetal.Com, 1. https://s3.amazonaws.com/desktopmetal /Studio-MDS-17-4-PH-stainlesssteel.pdf

Ghanbari, A., \& Attar, M. M. (2014). Surface free energy characterization and adhesion performance of mild steel treated based on zirconium conversion coating: A comparative study. Surface and Coatings Technology, 246, 26-33. https://doi.org/10.1016/j.surfcoat.2014.0 2.057

Jamaluddin, A. (2007). INJECTION MOLDING dan PENERAPANNYA di INDUSTRI MANUFAKTUR. http://anifmaterial.blogspot.com/2007/0 1/injection-molding-dan-penerapannyadi.html

Kekerasan, B. A. B. P. (2019). Bab 1. pengujian kekerasan. 1, 4-17.

Li, Y., Li, L., \& Khalil, K. A. (2007). Effect of powder loading on metal injection molding stainless steels. Journal of Materials Processing Technology, 183(2-3), 432-439. https://doi.org/10.1016/j.jmatprotec.200 6.10.039

Modeling, L. M., Measurement, F., Snowrift, O. N., Environmental, A. R., Regional, S., Power, E., Limited, G. C., Influence, T. H. E., Snow, O. F., On, F., Around, S., Embankment, T. H. E., Wind, I. N.,
Snow, B., Aspect, O. F., On, R. R., Distribution, S., Model, A. A. C., Simulation, N., ... Maciejowski, J. M. (2019). Title. Journal of Wind Engineering and Industrial Aerodynamics, 26(3), 1-4.

Permana, M. R. R. (2013). PENGARUH SUHU DAN WAKTU PROSES SOLVENT DEBINDING BERAT GREENPART PADA METAL INJECTION MOLDING SERBUK ALUMUNIUM.

Putra, R. H. S. (2018). Karakteristik Pada Logam Baja Paduan dengan Menggunakan Metoda X-Ray Fluorosence (XRF) dan Optical Emission Spectroscopy (OES). Universitas Negeri Yogyakarta.

Schaeffer, R. (2017). STUDI TENTANG PENGARUH JARAK (SPACER) TERHADAP KUALITAS KRISTAL LAPISAN TIPIS Sn ) HASIL PREPARASI DENGAN TEKNIK EVAPORASI VAKUM. In 2017 (Vol. 22).

Shieddieque, A. D., Virdhian, S., Muttahar, M. I. Z., \& Muttaqin, M. R. (2021). Effects of sintering variables on the physical and mechanical properties of metal injection molding molded 17-4 ph stainless steel. Materials Science Forum, 1028 MSF, 403-408. https://doi.org/10.4028/www.scientific.n et/MSF.1028.403

Zaky, M. T. (2004). Effect of solvent debinding variables on the shape maintenance of green molded bodies. Journal of Materials Science, 39(10), 3397-3402. https://doi.org/10.1023/B:JMSC.000002 6942.64551 .97 